\title{
Review
}

\section{Numerical Models for Sediment Transport by Tsunamis}

\author{
Kazuhisa Goto*,a and Fumihiko Imamura*
}

\begin{abstract}
Sediment transport by tsunamis causes serious human injury and damage to buildings, coastal topography, and marine ecosystems. To understand processes of sediment transport by tsunamis, experimental and numerical studies as well as field investigations are important. In this study, we summarize experimental and numerical models for transport of sandy sediments or a large block, and then discuss their limitations and possible improvements. Although some problems and difficulties remain, these models generally are able to reproduce experimental results, and they can be adapted to the modeling of sediment transport by real-scale tsunami events. When these models have been improved to handle mixed grain sizes and multiple blocks, it will be possible to estimate hydraulic properties (hydraulic force, current velocity, and inundation area) of historical and prehistoric tsunamis more precisely by constraining the models with information on existing tsunami deposits and boulders. Moreover, sediment transport models are useful for estimating the spatial distribution of sediments eroded and redeposited by tsunamis; thus, such models will be helpful in the selection of drilling sites for core samples in investigations of historical and prehistoric tsunami deposits.
\end{abstract}

Keywords : tsunami deposit, tsunami boulder, sediment transport model, hydraulic experiment

\section{Introduction}

On 26 December 2004, one of the largest tsunamis (the 2004 Indian Ocean tsunami) in human history struck coastal areas of countries surrounding the Indian Ocean, causing severe property damage and loss of life and forcing us to think anew about the fearful consequences of a tsunami disaster (Imamura et al., 2006). Tsunamis often strike at-risk countries, where there is an urgent need to improve countermeasures against tsunami disasters (e.g. Stone and Kerr, 2005). Once a large tsunami is generated, it has many severe consequences, including human injury and death and damage to buildings, coastal topography, and marine and coastal ecosystems. Moreover, large tsunamis remove sediments from the sea bottom and beaches and transport them landward or sea- ward. As a result, port function may be hampered by the deposition of large amounts of sediments (Takahashi et al., 1993), and fisheries and agricultural areas may be severely damaged by inundation of seawater or by burial under salty sediments (e.g. Nakaya et al., 2005). On the other hand, sandy sediments transported by a tsunami and deposited on land or on the sea bottom become part of the geologic record that can be used to identify historical or prehistoric tsunami events (e.g. Atwater, 1987 ; Minoura et al., 1987 ; Dawson et al., 1988 ; Nanayama et al., 2003 ; Cisternas et al., 2005).

Tsunami damage is related mainly to the hydraulic force and current velocity of a tsunami rather than to the inundation depth or wave height (e.g. Noji et al., 1993). Hydraulic force and current velocity can sometimes be estimated on the basis of information in aerial photographs

Received August 10, 2006. Accepted January 13, 2007.

* Tsunami Engineering Laboratory, Disaster Control Research Center Graduate School of Engineering, Tohoku University. 6-6-11-1106 Aoba, Aramaki, Aoba-ku, Sendai, 980-8579, Japan.

*a Corresponding author : kgoto@tsunami2.civil.tohoku.ac.jp 
using Cameron effect, if available (Takahashi et al., 1993), as well as from differences in inundation depth between the front and rear of structures (Matsutomi et al., 2005a, 2006). Moreover, in the case of the 2004 Indian Ocean tsunami, current velocity was estimated from video recordings (Borrero, 2005 ; Matsutomi et al., 2005a). However, in general, hydraulic force and current velocity are difficult to estimate from field observation data. Even when a field survey is conducted immediately after a tsunami event, many data on inundation depth and area and wave height are usually collected, but very few data on hydraulic force or current velocity are obtained.

Alternatively, might it be possible to estimate the hydraulic properties of a tsunami, in particular, hydraulic force and current velocity, from information recorded in tsunami deposits, such as deposit thickness, grain size, and spatial distribution? If so, then we might be able to estimate the nature and behavior of historical and prehistoric tsunamis in greater detail, which would be useful for evaluating the risk of future tsunami disasters in the same region as the deposits. Two approaches have been used to estimate hydraulic properties of tsunamis from tsunami deposits. A sedimentological approach has empirically estimated wave period and current velocity from the lithology, sedimentary structures, and grain size of tsunami deposits (e.g. Fujiwara et al., 2003 ; Fujiwara, 2004). On the other hand, experimental and numerical approaches reproduce the sediment transport processes of tsunamis (Fig. 1, e.g. Takahashi et al., 2000). For example, tsunami inundation processes have been estimated by using the spatial distribution of tsunami deposits to constrain a numerical model (Titov et al., 2001 ; Jaffe and Gelfenbaum, 2002 ; Koshimura et al., 2002).

For disaster prevention purposes, experimental and numerical models of sandy and block sediment transport by tsunamis have been developed by coastal engineers (Noji et al., 1993 ; Takahashi et al., 1993) seeking to maintain port function in the face of topographic changes caused by tsunami sedimentation and to clar-

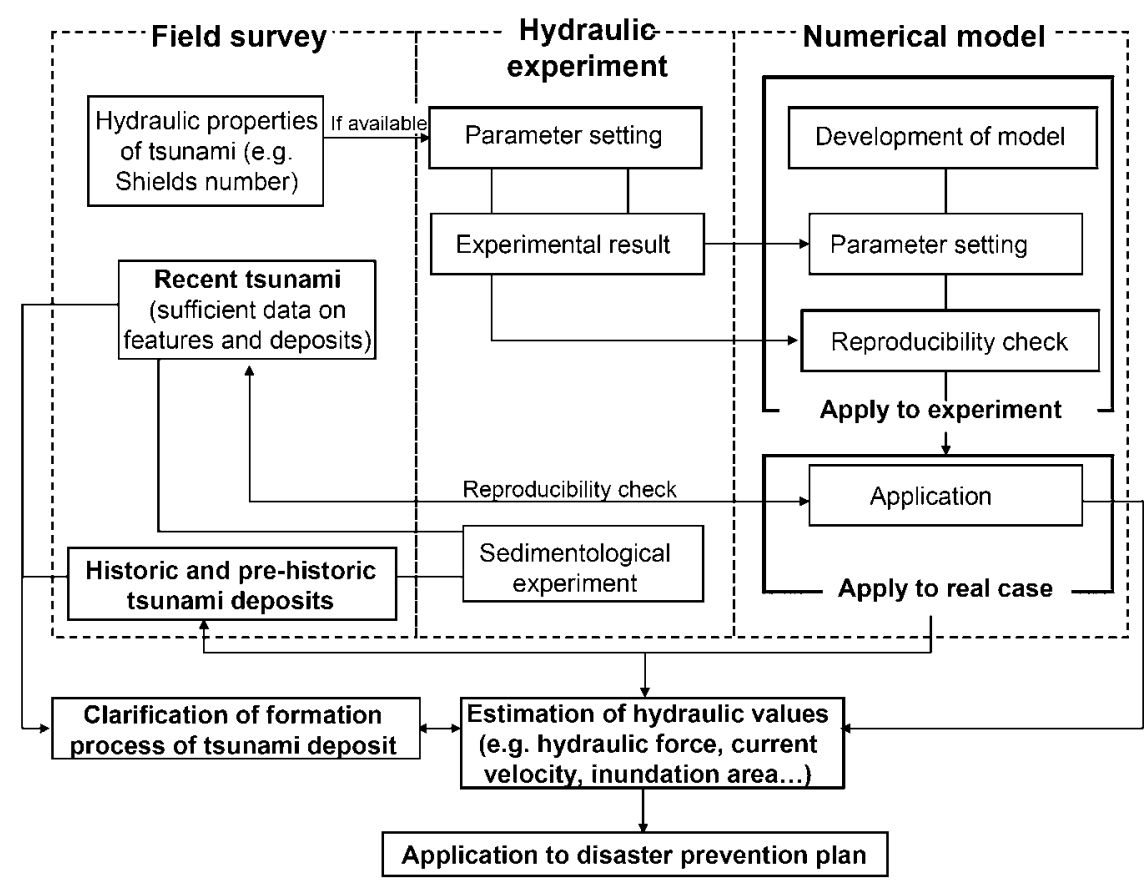

Fig. 1 A flowchart indicating the relationships among field surveys, hydraulic experiments, and numerical models for the clarification of sediment transport by tsunamis 
ify transport processes of large blocks, including tetrapods used in breakwater construction, by tsunamis. These models, which have recently received practical improvements by many researchers (Fujii et al., 1998 ; Takahashi et al., 1999, 2000 ; Imamura et al., 2001, in press ; Sugawara et al., 2003, 2004a ; Nishihata et al., 2005), are also useful for sedimentological and paleontological studies of tsunami deposits designed to clarify depositional processes. On the other hand, sedimentological and paleontological data on tsunami deposits provide important constraints on such models, and their accuracy and reproducibility are evaluated using such data (Fig. 1). Therefore, cooperation among investigators in the two research fields leads to complementary advantages and is critically important for future study of sediment transport by tsunamis. Here, we summarize hydraulic experiments and numerical models of sandy and block sediment transport, which have developed during the past 15 years, and discuss the current status of these models, their problems, and improvements.

\section{Hydraulic experiments and numerical calculation of tsunami inundation}

Real-time measurement of sediment transport by a tsunami is technically difficult at present ; thus, we observe instead sediment erosion, transport, and deposition by tsunamis. Not only sedimentological studies but also hydraulic experiments (Kato et al., 2000 ; Hasegawa et al., 2001 ; Sugawara et al., 2003, 2004b) and numerical analyses (Takahashi et al., 1993, 1999, 2000 ; Fujii et al., 1998 ; Sugawara et al., 2004a ; Nishihata et al., 2005) can be used to improve our understanding of sediment suspension, transport, and deposition.

At the Disaster Control Research Center, Tohoku University, hydraulic experiments are conducted in a water tank, $10 \mathrm{~m}$ long and $30 \mathrm{~cm}$ wide, with a flat floor (Fig. 2, e.g. Sugawara et al., 2004b ; Imamura et al., in press). A gate located $300 \mathrm{~cm}$ from the upstream end of the tank confines water in a storage tank, and a bore is generated by the rapid opening of the gate (Fig. 2). The initial water depth on the flat floor on the downstream side of the gate is $1.2 \mathrm{~cm}$.

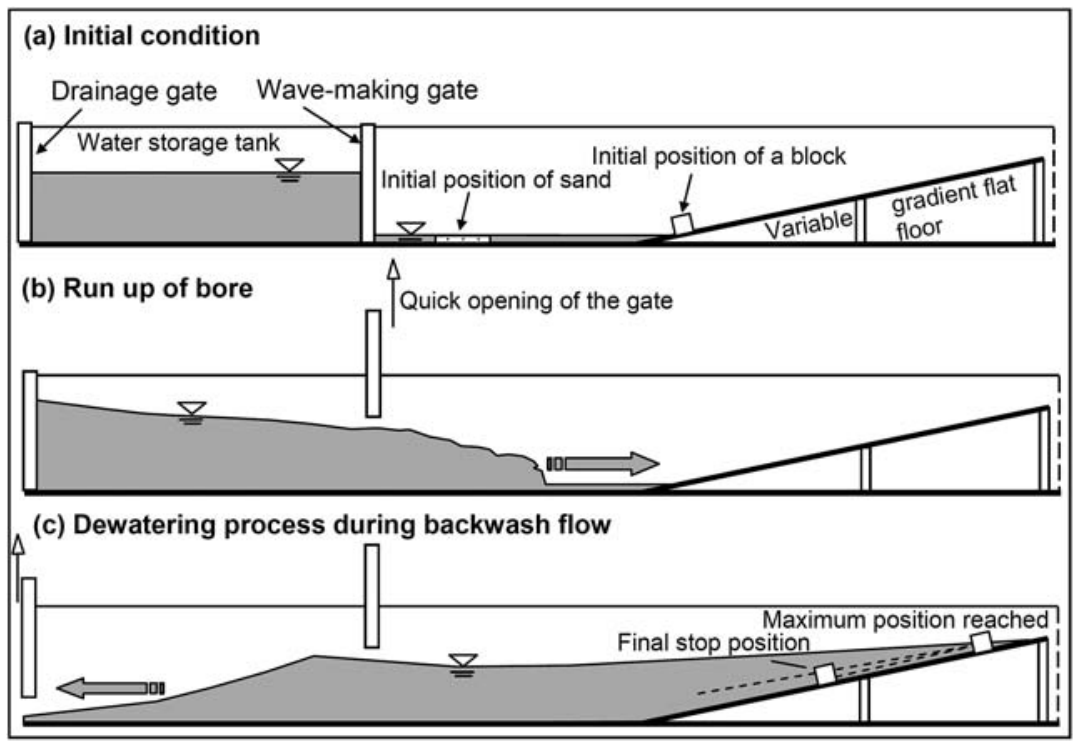

Fig. 2 Schematic diagrams showing a water tank for conducting hydraulic sediment transport experiments

(a) Initial condition, (b) generation and run-up of the bore after rapid opening of the gate, and (c) dewatering process during backwash flow. Sand and a block are set in their initial positions for each experiment. Modified from Imamura et al. (in press). 
The current velocity of the bore can be changed by adjusting the amount of water in the storage tank. A variable-gradient flat slope, used to simulate the shore, is at the downstream end of the tank. The surfaces of the flat floor and slope are smooth and impermeable, but bottom friction can be changed by using different slope materials. The generated bore runs up the slope, reaches a maximum inundation level, and then flows back toward the upstream side as backwash current. The backwash current is dewatered through a drainage gate in the upstream end of the storage tank. Using this system, we can measure the amount of sediments deposited and eroded by a single bore (Fig. 2).

Because of the restricted scale of the water tank, it is difficult to reproduce a real-scale tsunami wave in this tank. Therefore, the results must be interpreted in light of the principle of similitude. In general, the Froude number $F_{r}$ and nondimensional bed shear stress (Shields number) $\tau_{*}$ of experimental current are set to be close to the values of a putative tsunami wave current:

$$
\begin{aligned}
& F_{r}=\frac{u}{\sqrt{g h}} \\
& \tau_{*}=\frac{u_{*}^{2}}{s g d}: s=\frac{\rho_{s}-\rho_{f}}{\rho_{f}}
\end{aligned}
$$

where $u$ is velocity, $g$ is gravitational acceleration, $h$ is still-water depth, $u_{*}$ is shear velocity, $\rho_{s}$ and $\rho_{f}$ are sediment particle and fluid densities, respectively, and $d$ is particle diameter. In the water tank experiment, the Shields number is within a similar range to that of real-scale tsunamis (Sugawara et al., 2003). The slope gradient and current duration should also be adjusted to values similar to those of a putative tsunami wave current (Sugawara et al., 2004b). Further improvements of the water tank will be required for more detailed studies.

Before the calculation of the sediment transport process, accurate reproduction of the wave current is required. Shallow-water theory is used for numerical calculation of a tsunami propagation in the shallow region and run-up.

$$
\frac{\partial \eta}{\partial t}+\frac{\partial M}{\partial x}=0
$$

$$
\frac{\partial M}{\partial t}+\frac{\partial}{\partial x}\left(\frac{M^{2}}{D}\right)+g D \frac{\partial \eta}{\partial x}+\frac{g n^{2}}{D^{7 / 3}} M|M|=0
$$

where $\eta$ is the vertical displacement of the water surface above the still-water surface, $M$ is the discharge flux in the $x$ direction, $D$ is total water depth $(=h+\eta)$, and $n$ is Manning's roughness coefficient. Equations (2.3) and (2.4) represent the equations of continuity and motion, respectively. The staggered leap-frog method, a finite-difference method, is used to solve these equations numerically (Goto et al., 1997 ; Takahashi, 2004). The condition of the wave front is based on Kotani et al. (1998).

\section{Numerical model of sandy sediment transport}

\section{Background}

Tsunamis transport abundant sediments as bed load or suspended load (Takahashi et al., 1993). Sediment transport resulting in sand deposition damages farm crops (Nakaya et al., 2005), port functions (Takahashi et al., 1993 ; Tomita et al., 2006), thermal and nuclear power plants (Takahashi et al., 2000), and marine ecosystems (e.g. Comley et al., 2005) ; sand erosion damages buildings and coastal vegetation (Harada et al., 2002 ; Danielsen et al., 2005 ; Tanaka et al., 2005 ; Yanagisawa et al., 2006), and beach pollution caused by debris deposition accompanying beach sand movement damages tourism (Yasuda and Harada, 2005). Moreover, abundant debris floated in the tsunami wave currents of the 2004 Indian Ocean tsunami at Banda Aceh, Indonesia. It is one of the noticeable phenomena and enhanced the damage in the city center (e.g. Matsutomi et al., 2005b). Because coefficient of viscosity of water becomes high due to the mixture of fine sediment particles, viscosity of the tsunami wave current, which inundated on land and suspended large amount of sediments, might have become high, and thus the tsunami wave current might have easily drifted abundant debris.

By taking into account such complexities, numerical models of sediment transport can be useful for improving the reliability of disaster assessment. Moreover, sediment transport models are also useful for investigating the hydraulic properties and behavior of historical and pre- 
historic tsunamis both on land and in the sea (Takahashi et al., 1999, 2000). In view of these problems and considerations, numerical models of sandy sediment transport by tsunamis have been developed (Takahashi et al., 1993) and improved (Asai et al., 1998 ; Fujii et al., 1998 ; Takahashi et al., 1999, 2000 ; Nishihata et al., 2005). In this section, we describe a sediment transport model developed by Takahashi et al. (1993, 1999, 2000) and applied to experimental water tank results by Sugawara et al. (2004a), and summarize an example of its application and some of its problems and limitations.

\section{Numerical model}

Sandy sediments are transported as bed and suspended loads by tsunamis. Although in reality no clear boundary exists between these two layers, Takahashi et al. (2000) assumed two distinct layers in their model (Fig. 3). In this model, movement of sediments in the flow direction within the bed- and suspended-load layers, settling of sediments from the suspended layer to the bed-load layer, and the entrainment of sediments from the bed load to the suspended load layer are considered (Takahashi et al., 2000). In this model, fluxes are conserved in each layer (Fig. 3, lower panel). Takahashi et al. (2000) introduced the concept of the exchange load $w_{e x}$ to describe the net load, the balance between suspension and settling of sediments between the two layers. The governing equations of their model are as follows :

$$
\begin{aligned}
& \frac{\partial Z_{B}}{\partial t}+\frac{1}{1-\lambda}\left(\frac{\partial q_{B}}{\partial x}+w_{e x}\right)=0 \\
& \frac{\partial \bar{C}_{s} M}{\partial x}-w_{e x}+\frac{\partial \bar{C}_{s} h}{\partial t}=0 \\
& w_{e x}=\varepsilon_{z} \frac{\partial C}{\partial z}-w_{0} C
\end{aligned}
$$

where $Z_{B}$ is height of the bed above the reference level, $\lambda$ is porosity, $q_{B}$ is bed-load rate, $M$ is flow flux, $C_{s}$ is the mean particle concentration in the suspended-load layer, $h$ is the water depth, $\varepsilon_{z}$ is the vertical diffusion coefficient, $C$ is the suspended-sediment concentration, and $w_{0}$ is the settling velocity. Equations (3.1) and (3.2) represent the equations of continuity in the bedload and suspended-load layers, respectively.

Takahashi et al. (2000) adopted equations of a non-dimensional bed load and a non-dimensional exchange load for tsunami based on the hy-
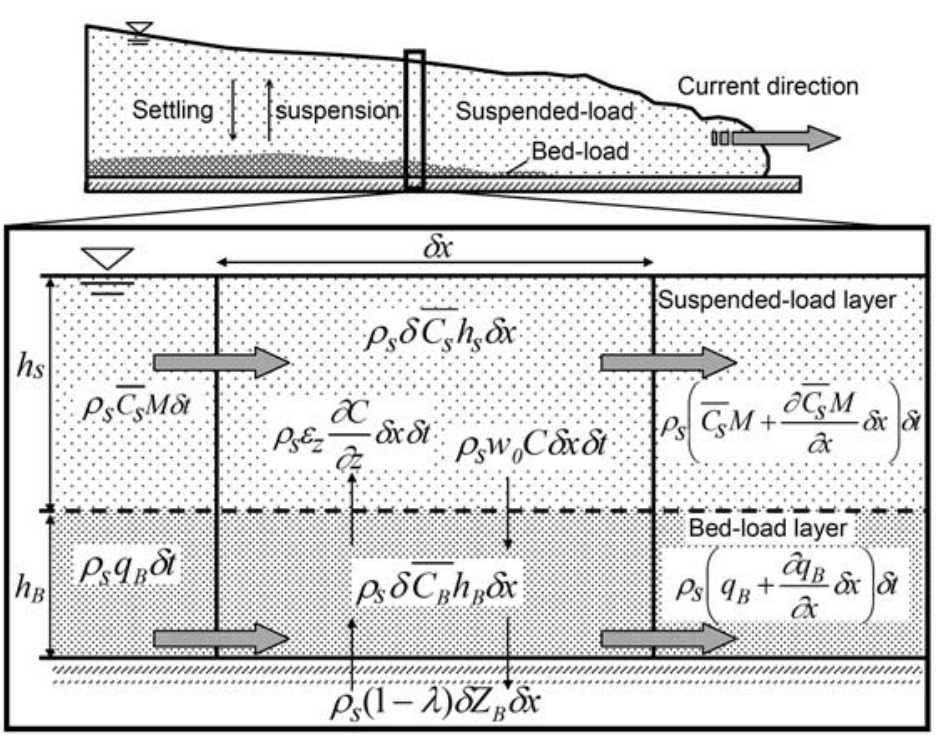

Fig. 3 Diagram showing the modeling of two separate layers (suspended-load layer and bed-load layer) based on Takahashi et al. (2000)

$\bar{C}_{B}$ is the mean concentration of the bed-load layer, and $h_{B}$ is the thickness of the bed-load layer. Other parameters are defined in the text. 
draulic experiment, because current velocity of the tsunami is faster than the stream flow and these equations for stream flow are inapplicable to the tsunami. According to Takahashi et al. (2000), the nondimensional bed-load transport rate $\Phi_{B}$ and the nondimensional exchange rate $\Psi_{\text {rise }}$ can be empirically related to the Shields number as follows :

$$
\begin{aligned}
& \Phi_{B}=21 \tau_{*}{ }^{3 / 2} \\
& \Psi_{\text {rise }}=0.012 \tau_{*}{ }^{2}
\end{aligned}
$$

Based on equations (3.4) and (3.5), Takahashi et al. (2000) proposed the following equations for the bed load and exchange load of a tsunami.

$$
\begin{aligned}
& q_{B}=21 \sqrt{\operatorname{sgd} d^{3}} \tau_{*}{ }^{3 / 2} \\
& w_{e x}=0.012 \sqrt{\operatorname{sg} d} \tau_{*}{ }^{2}-w_{0} \bar{C}_{s}
\end{aligned}
$$

where $s$ is the relative density of the sand particles.

\section{Application examples and problems}

Sugawara et al. (2004a) applied this numerical model to experimental hydraulic results (Figs. 4-a, 5). Because the hydraulic experiment reproduced wave currents well, the experimental results were suitable for evaluating the validity of the sediment transport model. The calculation results generally reproduced the characteristics of the experimental results, including the sedimentation peak at the base of the slope and a wedged-shape sediment deposit on the slope (Fig. 5, Sugawara et al., 2004a). However, calculation results for nondimensional sedimentation sand and remnant sand volumes, which represent the nondimensional sand volume deposited by the run-up current and the sand

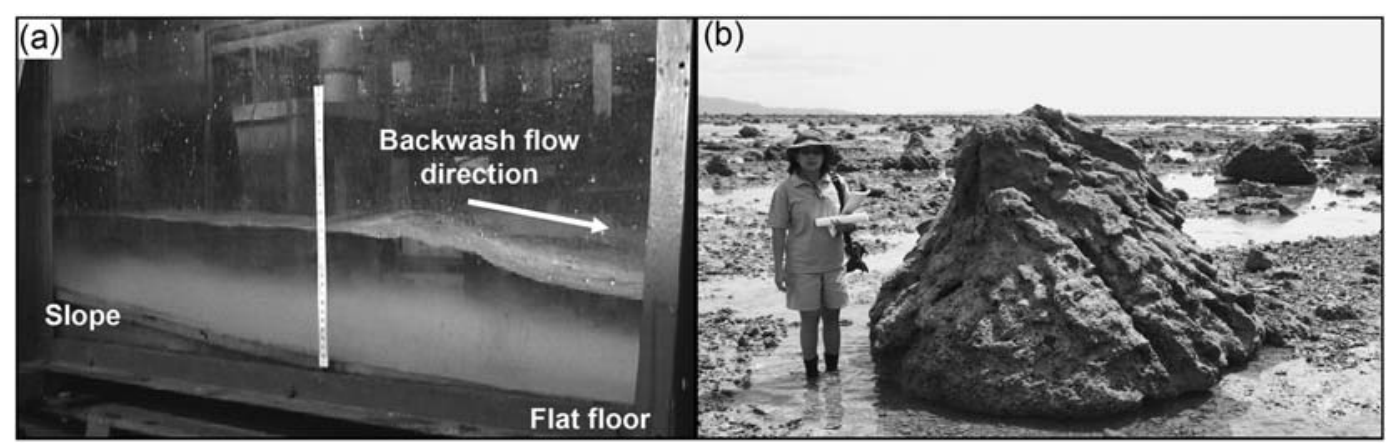

Fig. 4 Photographs of (a) experimental results for sandy sediment transport, and (b) a coral fragment transported by the 2004 Indian Ocean tsunami at Pakarang Cape, Thailand

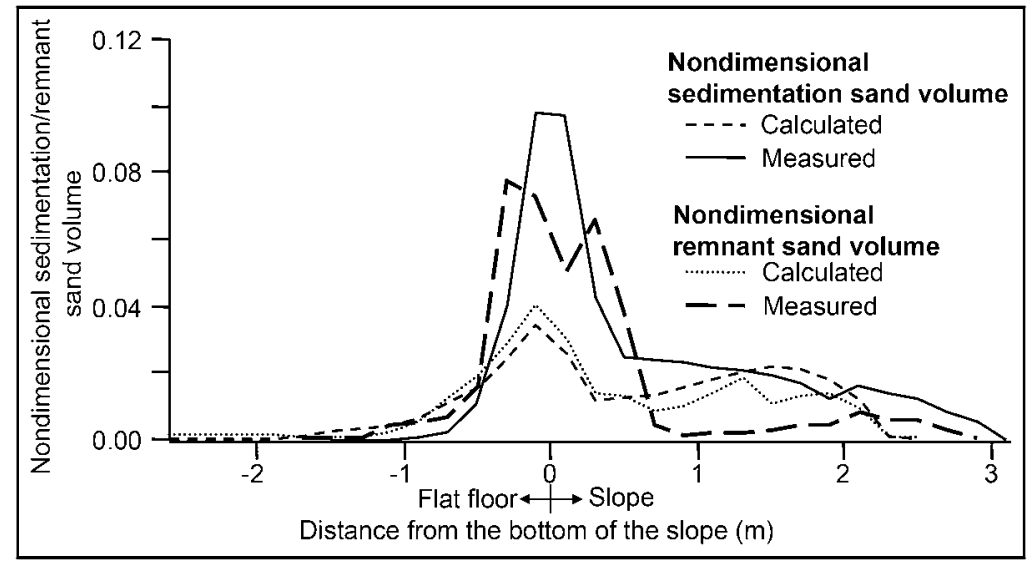

Fig. 5 Comparison of experimental and numerical results for sandy sediment transport Modified from Sugawara et al. (2004a). 
volume resting on the slope after the passage of the backwash, respectively, were considerably lower than the values obtained experimentally. In particular, the volume of sand transported by the backwash current was underestimated. These results were probably affected by problems related with the accuracy of the bed load and exchange load equations, and the low reproducibility of the hydraulic experiment results (Sugawara et al., 2004a). In addition, a grain size effect could be an important factor for the inconsistency between the experimental and numerical results.

Sugawara et al. (2004a) used sand of mixed grain size $(150-600 \mu \mathrm{m})$ for the hydraulic experiment in an attempt to reproduce the landward-fining feature of tsunami deposits (Minoura et al., 1997 ; Moore, 2000). However, fine grains, because they easily become suspended and slow to settle, are in general more susceptible to current velocity and are thus more movable than coarse grains (e.g. Julien, 1995). However, a numerical model of sediment transport taking mixed grain sizes into account has not yet been developed for tsunami sedimentation. Therefore, fully sorted sand (average grain size) is assumed by the model. In other words, differences in the sediment transport process that depend on grain size have not been incorporated into the model. As a result, the model overestimates the amount of coarse sediments larger than the average grain size and underestimates the amount of fine sediments. Considering that actual tsunamis transport sediments with a wide range of grain sizes, the accuracy of the calculation results decline when we apply the existing model to real-scale sediment transport.

Recently, a sediment transport model developed for stream flow is extended in order to incorporate mixed grain sizes into the calculations (e.g. Sekine, 2001), although some problems and difficulties remain. In the future, it will be important to apply the method to improve modeling of sediment transport by tsunamis. With the improved model, we will be able to discuss characteristic features of tsunami deposits such as landward fining.

\section{Numerical model for boulder transport}

\section{Background}

It is commonly believed that large tsunami waves can transport huge boulders as well as sandy sediments (e.g. Kato and Kimura, 1983). A typical example is the more than 300 boulders of reef scattered along the shore of Ishigaki Island, Japan (e.g. Kato and Kimura, 1983 ; Nakata and Kawana, 1993). These reef boulders, called "tsunami-ishi" in Japanese, are thought to have been transported by the 1771 Meiwa Yaeyama tsunami, which, according to historical documents, had a wave height of $\sim 30 \mathrm{~m}$. Moreover, abundant meters-long boulders of coral fragments were transported by the tsunamis associated with the 1883 Krakatau volcanic eruption (Simkin and Fiske, 1983) and the 2004 Indian Ocean tsunami (Fig. 4-b, Goto et al., in press a). Similar large boulders of possible historic or prehistoric tsunami or hurricane origin have been reported from the coastal areas of Japan, Australia, Italy, the United States (Hawaii), Spain, and Portugal (e.g. Noji et al., 1993 ; Mastronuzzi and Sanso, 2000 ; Nott, 2000, 2004 ; Noormets et al., 2002, 2004 ; Whelan and Kelletat, 2005 ; Scheffers and Kelletat, 2005 ; Goff et al., 2006).

The ability of a tsunami to transport boulders is closely related to the hydraulic force of the tsunami; thus, estimation of the hydraulic force and current velocity necessary to transport such boulders is easier than those of sandy tsunami deposits. For example, the minimum current velocity necessary to move a boulder can be estimated from the weight and shape of the boulder (e.g. Noormets et al., 2004 ; Nott, 2004). However, numerical calculations are required to understand in detail the transport process and variations in the hydraulic force during boulder transport. In this section, we summarize a numerical model for boulder transport by tsunamis developed by Noji et al. (1993) and improved by Imamura et al. (2001, in press).

\section{Numerical model}

External forces, including those produced by the tsunami wave current, acting on the block are represented by hydraulic force $F_{m}$, bottom frictional force $F_{b}$, and gravitational force $F_{g}$ along the slope direction (Fig. 6, Noji et al., 1993). 


$$
\rho_{s} V \ddot{X}=F_{m}-F_{b}-F_{g}
$$

where $\rho_{s}$ is the density of the block, $V$ is the volume of the block, and $X$ is the position of the block in the $x$-direction. $F_{m}$ represents the sum of the forces of drag and inertia (Noji et al., 1993).

$$
\begin{aligned}
F_{m}= & C_{D} \frac{1}{2} \rho_{f} A(U-\dot{X})|U-\dot{X}|+ \\
& C_{M} \rho_{f} V \dot{U}-\left(C_{M}-1\right) \rho_{f} V \ddot{X}
\end{aligned}
$$

where $U$ is the current velocity at the block position, $A$ is the projected area of the block against the current, and $C_{D}$ and $C_{M}$ are coefficients of drag and mass, respectively. $F_{b}$ and $F_{g}$ are represented as follows.

$$
\begin{aligned}
& F_{b}=\mu\left(\rho_{s}-\rho_{f}\right) V g \cos \theta \frac{\dot{X}}{|\dot{X}|} \\
& F_{g}=\left(\rho_{s}-\rho_{f}\right) V g \sin \theta
\end{aligned}
$$

where $\theta$ is the angle of the slope at the position of the block and $\mu$ is the coefficient of friction.

$\mu$ is constant when the block is transported by sliding, but it is also possible for the block to be transported by rolling or saltation, depending on the block shape and the hydraulic force of the tsunami (Fig. 6). Therefore, Imamura et al. (in press) empirically introduced a variable coefficient of friction $\mu(t)$ based on hydraulic experiments by assuming that the coefficient of friction decreases as a result of the reduction in ground contact time when the block is transported by rolling or saltation (Fig. 6).

$$
\frac{\mu(t)}{\mu_{0}}=\frac{2.2}{\beta^{2}+2.2}
$$

where $\mu_{0}$ is the coefficient of dynamic friction during sliding and $\beta$ is a parameter that indicates the degree of contact between the block and the floor (Imamura et al., in press).

\section{Application examples and problems}

Figure 7 displays the experimental and numerical results of Imamura et al. (in press). In this experiment, the block was mainly transported by rolling or saltation (Imamura et al., in press). The numerical results obtained by using a variable coefficient of friction, which assume transport of the block by rolling or saltation, were in good agreement with the experimental results. Numerical results obtained by using the variable coefficient of friction were

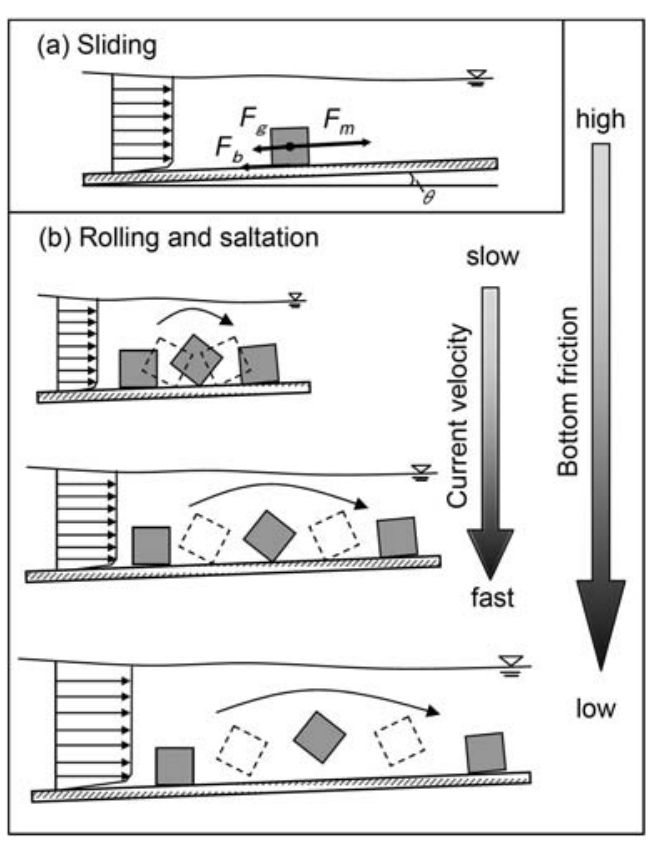

Fig. 6 Schematic diagram showing variation in transport mode of a block during hydraulic experiments

The transport mode is (a) sliding or (b) rolling and saltation, depending on the shape and weight of the block as well as on the current velocity. Modified from Imamura et al. (in press).

within the error span of the experimental results, although the final stop position of the block in the experimental results showed considerable scatter, especially when the water depth in the storage tank was $30 \mathrm{~cm}$.

This model is applicable only to the movement of a single boulder. However, tsunamis usually transport numerous boulders at the same time (Kato and Kimura, 1983 ; Simkin and Fiske, 1983 ; Goto et al., in press a, b). Therefore, the effect of collisions between boulders and the shielding effect of boulders should be considered in a future model.

\section{Limitations of numerical models for sediment transport and needed im- provements}

Although some problems and difficulties remain and future improvement of models is required, models of sandy sediment and block transport by tsunamis generally reproduce ex- 

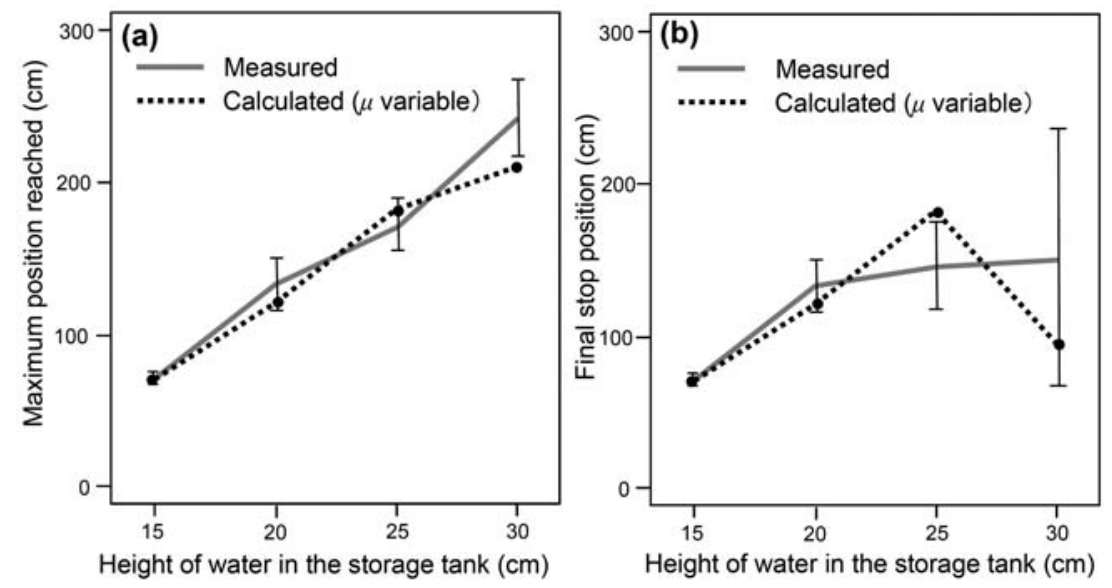

Fig. 7 Comparison of experimental and numerical results of block transport Vertical axes indicate (a) the maximum position reached by the block on the slope and (b) its final stop position (see Fig. 2-c). Horizontal axes indicate the initial depth of water in the water storage tank $(\mathrm{cm})$, which determines the current velocity of the bore. Variable $\mu$ assumes that the block moves by sliding, rolling, and saltation. Numerical results using variable $\mu$ were in good agreement with the experimental results. Modified from Imamura et al. (in press).

perimental results. A sediment transport model for sandy sediments was applied to investigate the bathymetric changes at Kesennuma Bay caused by the 1960 Chilean tsunami (Takahashi et al., 2000). It is important to note that the reproducibility of sediment transport is highly dependent on the reproducibility of current velocity of the tsunami in the numerical model, and the distribution pattern of areas of erosion and deposition were well reproduced by this model when the current velocity was well reproduced (Takahashi et al., 2000). Using the model, it is possible to estimate areas of redeposition and erosion in the bay and offshore. This kind of information could be useful for selecting drilling points for the investigation of historical and prehistoric tsunami deposits. In this way, the model is being scaled up to make it more applicable to real-scale sediment transport by tsunamis. However, because conditions before and after a tsunami are well known in only a few cases, applicability of the model to real-scale tsunami events has not yet been well verified.

Moreover, the sandy sediment transport model was intended to model sediment transport in the sea; though its applicability for modeling transport on land has not yet been verified.
Since the late 1980s, studies of tsunami deposits have become popular, and data on tsunami deposits as well as on tsunami wave height, inundation area, and topography have been collected by field surveys conducted just after tsunami events such as the 1992 Flores tsunami (Shi et al., 1995), the 1993 Hokkaido Nansei-Oki tsunami (Nanayama and Shigeno, 2004, 2006), the 1998 Papua New Guinea tsunami (Gelfenbaum et al., 2001), and the 2004 Indian Ocean tsunami (e.g. Moore et al., 2006 ; Fujino et al., in press ; Goto et al., in press b). In these cases, reliable field data on tsunamis and tsunami deposits were obtained, allowing us to investigate the sedimentary processes of tsunami deposits and to estimate hydraulic properties of tsunamis with field data, as constraints of the model in the future.

In contrast, estimation of hydraulic properties of tsunamis from past tsunami deposits in the geologic age by the model is usually difficult, because of fragmentary data and the many uncertainties involved. A sedimentological approach based on sedimentary structures and grain size (e.g. Fujiwara et al., 2003) is probably more suitable for estimating tsunami hydraulic properties from tsunami deposits in the geologic age. 
The block transport model was also applied to a tsunami boulder on Ishigaki Island, Japan, which was transported by the 1771 MeiwaYaeyama great tsunami (Imamura et al., 2001, in press). The transport process and the distance that the boulder was transported was modeled numerically and the results were compared with descriptions in historical documents. However, the validity and applicability of the block transport model to real-scale tsunami events needs to be checked. For example, the 2004 Indian Ocean tsunami transported large reef boulders, up to $4 \mathrm{~m}$ long, landward at Pakarang Cape, Thailand. The field observations suggest that the first, eastward-directed tsunami wave struck the reef rocks, which were originally located on the shallow sea bottom near the reef edge (300 to $600 \mathrm{~m}$ offshore), thereby detached the boulders and transported them shoreward (Goto et al., in press a). No boulders were found on land, indicating that the hydraulic force of the tsunami wave rapidly decreased on reaching the land. In this case, the original and stop positions of boulders are well known, as are the tsunami wave height, inundation area, and topography (Goto et al., in press a). Therefore, the block transport model can be applied in this case to investigate the transport process of boulders.

It was reported that a number of tetrapods were transported inland by the 1983 NihonkaiChubu tsunami (Noji et al., 1993). To clarify the transport process and assess future risk, a numerical model of transport of multiple blocks should be developed. As noted above, the present block transport model is applicable only to the movement of a single block. Effects of collisions among blocks and the shielding effect of blocks should be considered in the future model.

\section{Conclusion}

In this paper, we described sediment transport models that have been developed for sandy sediments and a boulder. These models generally reproduce experimental results, although improvement is still required. When these models are improved to be able to treat mixed grain sizes and multiple numbers of blocks, we will be able to use them to estimate hydraulic prop- erties of historical and prehistoric tsunamis more precisely from tsunami deposits and boulders. On the other hand, for further improvement of the models, it will be important to investigate thickness, grain size, sedimentary structures, and spatial distribution of tsunami deposits as well as the wave height and inundation area of tsunamis in the same area during field surveys after future tsunami events.

\section{Acknowledgements}

We thank T. Takahashi and O. Fujiwara, who critically read the manuscript and gave us many valuable suggestions. The study was partly supported by research funds donated by a Grant-in-Aid for Scientific Research from the Japan Society for the Promotion of Science (no. 17740331).

\section{References}

Asai, D., Imamura, F., Shuto, N. and Takahashi, T. (1998) Estimated tsunami heights and sand transport at Iruma Izu in the 1854 Tokai Earthquake. Proceedings of Coastal Engineering, JSCE, 45, 371375. (J)

Atwater, B.F. (1987) Evidence for great Holocene earthquakes along the outer coast of Washington State. Science, 236, 942-944.

Borrero, J.C. (2005) Field survey of northern Sumatra and Banda Aceh, Indonesia after the tsunami and earthquake of 26 December 2004. Seismological Research Letters, 76, 309-317.

Cisternas, M., Atwater, B. F., Torrejón, F., Sawai, Y., Machuca, G., Lagos, M., Eipert, A., Youlton, C., Salgado, I., Kamataki, T., Shishikura, M., Rajendran, C. P., Malik, J.K., Rizal, Y. and Husni, M. (2005) Predecessors of the giant 1960 Chile earthquake. Nature, 437, 404-407.

Comley, J., O’Farrell, S., Hamylton, S., Ingwersen, C. and Walker, R. (2005) The impact of the December 2004 Indian Ocean tsunami on the coral reef resources of $\mathrm{Mu}$ Ko Surin Marine National Park, Thailand. 26 p, Report of Coral Cay Conservation.

Danielsen, F., Sorensen, M.K., Olwig, M.F., Selvam, V., Parish, F., Burgess, N.D., Hiraishi, T., Karunagaran, V.M., Rasmussen, M.S., Hansen, L.B., Quarto, A. and Suryadiputra, N. (2005) The Asian tsunami : A protective role for coastal vegetation. Science, 310, 643.

Dawson, A.G., Long, D. and Smith, D.E. (1988) The Storegga Slides: Evidence from eastern Scotland for a possible tsunami. Marine Geology, 82, 271-276.

Fujii, N., Ohmori, M., Takao, M., Kanayama, S. and Ohtani, H. (1998) On the deformation of the sea bottom topography due to tsunami. Proceedings of Coastal Engineering, JSCE, 45, 376-380. (J) 
Fujino, S., Naruse, H., Suphawajruksakul, A., Jarupongsakul, T., Murayama, M. and Ichihara, N. (in press) Thickness and grain-size distribution of Indian Ocean tsunami deposits at Khao Lak and Phra Thong Island, south-western Thailand. Shiki, T., Tsuji, Y., Yamazaki, T. and Minoura, K. (eds.) Tsunamiites-Features and implications. Elsevier.

Fujiwara, O. (2004) Sedimentological and paleontological characteristics of tsunami deposits. Fujiwara, O., Ikehara, K. and Nanayama, F. (eds.) Earthquakeinduced event deposits-From deep-sea to on land : 35-44, Memoirs of the Geological Society of Japan, 58. $(\mathrm{J}+\mathrm{E})$

Fujiwara, O., Kamataki, T. and Tamura, T. (2003) Grainsize distribution of tsunami deposits reflecting the tsunami waveform : an example from a Holocene drowned valley on the southern Boso Peninsula, east Japan. The Quaternary Research (DaiyonkiKenkyu), 42, 67-81. (J+E)

Gelfenbaum, G., Jaffe, B., Nongkas, M. and Davies, H. L. (2001) Sedimentary deposits from the 17 July 1998 Papua New Guinea tsunami. Proceedings of International Tsunami Symposium, 449-452.

Goff, J., Dudley, W.C., de Maintenon, M. J., Cain, G. and Coney, J.P. (2006) The largest local tsunami in 20th century Hawaii. Marine Geology, 226, 65-79.

Goto, C., Ogawa, Y., Shuto, N. and Imamura, F. (1997) IUGG/IOC Time Project, Numerical method of tsunami simulation with the Leap-Frog Scheme. 130 p, IOC Manuals and Guides, UNESCO, 35.

Goto, K., Chavanich, S., Imamura, F., Kunthasap, P., Matsui, T., Minoura, K., Sugawara, D. and Yanagisawa, H. (in press a) Distribution, origin and transport process of boulders transport by the 2004 Indian Ocean tsunami at Pakarang Cape, Thailand. Sedimentary Geology. doi : 10.1016/j. sedgeo. 2007.09. 004.

Goto, K., Imamura, F., Keerthi, N., Kunthasap, P., Matsui, T., Minoura, K., Ruangrassamee, A., Sugawara, D. and Supharatid, S. (in press b) Distribution and significance of the 2004 Indian Ocean tsunami deposits - Initial results from Thailand and Sri Lanka. Shiki, T., Tsuji, Y., Yamazaki, T. and Minoura, K. (eds.) Tsunamiites-Features and implications. Elsevier.

Harada, K., Imamura, F. and Hiraishi, T. (2002) Experimental study on the effect in reducing tsunami by the coastal permeable structure. Proceedings of the 12th International Offshore and Polar Engineering Conference, The International Society of Offshore and Polar Engineers, Cupertino, 652-658.

Hasegawa, S., Takahashi, T. and Uehata, Y. (2001) Hydraulic experiment on sediment due to tsunami run-up. Proceedings of Coastal Engineering, JSCE, 48, 311-315. (J)

Imamura, F., Goto, K. and Ohkubo, S. (in press) A numerical model for the transport of a boulder by tsunami. Journal of Geophysical Research-Ocean. doi : 10.1029/2007JC004170.
Imamura, F., Koshimura, S., Goto, K., Yanagisawa, H. and Iwabuchi, Y. (2006) Global disaster: The 2004 Indian Ocean tsunami. Journal of Disaster Research, 1, 131-135.

Imamura, F., Yoshida, I. and Moore, A. (2001) Numerical study of the 1771 Meiwa tsunami at Ishigaki Island, Okinawa and the movement of the tsunami stones. Proceedings of Coastal Engineering, JSCE, 48, 346-350. ( J)

Jaffe, B.E. and Gelfenbaum, G. (2002) Using tsunami deposits to improve assessment of tsunami risk. Solution to Coastal Disasters, Conference Proceedings, ASCE, 836-847.

Julien, P.Y. (1995) Erosion and Sedimentation. 280 p, Cambridge University Press.

Kato, F., Sato, S. and Yeh, H. (2000) Large-scale experiment on dynamic response of sand bed around a cylinder due to tsunami. Coastal Engineering, 27, 1848-1859.

Kato, Y. and Kimura, M. (1983) Age and origin of so-called "Tsunami-ishi", Ishigaki Island, Okinawa prefecture. Journal of the Geological Society of Japan, 89, 471-474. (J+E)

Koshimura, S., Mofjeld, H.O., Gonzalez, F.I. and Moore, A.L. (2002) Modeling the 1100 BP paleotsunami in Puget Sound, Washington. Geophysical Research Letters, 20, 1948, doi : 10.1029/2002GL015170.

Kotani, M., Imamura, F. and Shuto, N. (1998) Tsunami run-up simulation and damage estimation by using GIS. Proceedings of Coastal Engineering, JSCE, 45, 356-360. (J)

Mastronuzzi, G. and Sanso, P. (2000) Boulders transport by catastrophic waves along the Ionian coast of Apulia (southern Italy). Marine Geology, 170, 93103.

Matsutomi, H., Sakakiyama, T., Nugroho, S. and Matsuyama, M. (2006) Aspects of inundated flow due to the 2004 Indian Ocean tsunami. Coastal Engineering Journal, 48, 167-195.

Matsutomi, H., Sakakiyama, T., Nugroho, S., Tsuji, Y., Tanioka, Y., Nishimura, Y., Kamataki, T., Murakami, Y., Matsuyama, M. and Kurizuka, K. (2005a) The 2004 Indian Ocean tsunami at Banda Ache and the environs and problems from a viewpoint of damage estimation. Annual Journal of Coastal Engineering, JSCE, 52, 1366-1370. (J)

Matsutomi, H., Takahashi, T., Matsuyama, M., Harada, K., Hiraishi, T., Supartid, S. and Nakusakul, S. (2005 b) The 2004 off Sumatra earthquake tsunami and damage at Khao Lak and Phuket island in Thailand. Annual Journal of Coastal Engineering, JSCE, 52, 1356-1360. (J)

Minoura, K., Imamura, F., Takahashi, T. and Shuto, N. (1997) Sequence of sedimentation processes caused by the 1992 Flores tsunami : Evidence from Babi Island. Geology, 25, 523-526.

Minoura, K., Nakaya, S. and Sato, H. (1987) Traces of tsunamis recorded in lake deposits-An example from Jusan, Shiura-mura, Aomori-. Journal of Seis- 
mological Society of Japan, 40, 183-196. (J+E)

Moore, A.L. (2000) Landward fining in onshore gravel as evidence for a late Pleistocene tsunami on Molokai, Hawaii. Geology, 28, 247-250.

Moore, A., Nishimura, Y., Gelfenbaum, G., Kamataki, T. and Triyono, R. (2006) Sedimentary deposits of the 26 December 2004 tsunami on the northwest coast of Aceh, Indonesia. Earth Planets Space, 58, 253-258.

Nakata, T. and Kawana, T. (1993) Historical and prehistorical large tsunamis in the southern Ryukyu, Japan. Proceedings of IUGG/IOC International Tsunami Symposium, 297-307.

Nakaya, T., Tanji, H. and Kiri, H. (2005) Field survey of agricultural damage in southern part of Thailand due to the Indian Ocean tsunami. Annual Journal of Coastal Engineering, JSCE, 52, 1361-1365. (J)

Nanayama, F., Satake, K., Furukawa, R., Shimokawa, K., Atwater, B.F., Shigeno, K. and Yamaki, S. (2003) Unusually large earthquakes inferred from tsunami deposits along the Kuril trench. Nature, 424, 660-663.

Nanayama, F. and Shigeno, K. (2004) An overview of onshore tsunami deposits in coastal lowlands and our sedimentological criteria to recognize them. Fujiwara, O., Ikehara, K. and Nanayama, F. (eds.) Earthquake-induced event deposits-From deep-sea to on land : 19-33, Memoirs of the Geological Society of Japan, $58 .(\mathrm{J}+\mathrm{E})$

Nanayama, F. and Shigeno, K. (2006) Inflow and outflow facies from the 1993 tsunami in southwest Hokkaido. Sedimentary Geology, 187, 139-158.

Nishihata, T., Tajima, Y. and Moriya, Y. (2005) Study on the dynamic topography change due to tsunami attacks at Kirinda Port-The December 26, 2004 earthquake tsunami of Indian Ocean. Annual Journal of Coastal Engineering, JSCE, 52, 1386-1390. (J)

Noji, M., Imamura, F. and Shuto, N. (1993) Numerical simulation of movement of large rocks transported by tsunamis. Proceedings of IUGG/IOC International Tsunami Symposium, 189-197.

Noormets, R., Crook, K.A.W. and Felton, E.A. (2004) Sedimentology of rocky shorelines : 3 : Hydrodynamics of megaclast emplacement and transport on a shore platform, Oahu, Hawaii. Sedimentary Geology, 172, 41-65.

Noormets, R., Felton, E.A. and Crook, K.A.W. (2002) Sedimentology of rocky shorelines : 2. Shoreline megaclasts on the north shore of Oahu, Hawaiiorigins and history. Sedimentary Geology, 150, 3145.

Nott, J. (2000) Records of prehistoric tsunamis from boulder deposits : evidence from Australia. Science of Tsunami Hazards, 18, 3-14.

Nott, J. (2004) The tsunami hypothesis-comparisons of the field evidence against the effects, on the Western Australian coast, of some of the most powerful storms on Earth. Marine Geology, 208, 112.
Scheffers, A. and Kelletat, D. (2005) Tsunami relics on the coastal landscape west of Lisbon, Portugal. Science of Tsunami Hazards, 23, 3-16.

Sekine, M. (2001) New attempt of numerical simulation of sand wave formation based on the analysis of sediment particle motion. Journal of Hydraulic, Coastal and Environmental Engineering, 57, 85-92. (J)

Shi, S., Dawson, A.G. and Smith, D.E. (1995) Coastal sedimentation associated with the December $12^{\text {th }}$, 1992 tsunami in Flores, Indonesia. Pure and Applied Geophysics, 144, 525-536.

Simkin, T. and Fiske, R.S. (1983) Krakatau, 1883 : the volcanic eruption and its effects. $464 \mathrm{p}$, Smithsonian Inst. Press.

Stone, R. and Kerr, R. (2005) Girding for the next killer wave. Science, 310, 1602-1605.

Sugawara, D., Minoura, K., Imamura, F., Hirota, T., Sugawara, M. and Ohkubo, S. (2004b) Hydraulic experiments regarding tsunami sedimentation. Fujiwara, O., Ikehara, K. and Nanayama, F. (eds.) Earthquake-induced event deposits-From deep-sea to on land : 153-162, Memoirs of the Geological Society of Japan, 58. $(\mathrm{J}+\mathrm{E})$

Sugawara, M., Ohkubo, S. and Imamura, F. (2004a) Basic study on sand sedimentation by a tsunami on an uniform slope. Tohoku Journal of Natural Disaster Science, 40, 265-270. (J)

Sugawara, M., Ohkubo, S., Sugawara, D., Minoura, K. and Imamura, F. (2003) Hydraulic experiment of sand and stone movements by a tsunami on a uniform slope. Proceedings of Coastal Engineering, JSCE, 50, 266-270. (J)

Takahashi, T. (2004) Application of numerical simulation to tsunami disaster prevention. Journal of Japan Society of Computational Fluid Dynamics, 12, 23-32. (J)

Takahashi, T., Imamura, F. and Shuto, N. (1993) Numerical simulation of topography change due to tsunamis. Proceedings of the IUGG/IOC International Tsunami Symposium, 243-255.

Takahashi, T., Shuto, N., Imamura, F. and Asai, D. (1999) A movable bed model for tsunamis with exchange rate between bed load layer and suspended layer. Proceedings of Coastal Engineering, JSCE, 46, 606-610. (J)

Takahashi, T., Shuto, N., Imamura, F. and Asai, D. (2000) Modeling sediment transport due to tsunamis with exchange rate between bed load layer and suspended load layer. Proceedings of the International Conference on Coastal Engineering, ASCE, 1508-1519.

Tanaka, N., Sasaki, Y., Yutani, K. and Homchuen, S. (2005) Effect of forest width and tree-species difference for tsunami protection considering the disaster caused by the Indian Ocean tsunami at Thailand. Annual Journal of Coastal Engineering, JSCE, 52, 1346-1350. (J)

Titov, V.V., Jaffe, B., Gonzalez, F.I. and Gelfenbaum, 
G. (2001) Re-evaluating source mechanism for the 1998 Papua New Guinea tsunami using revised slump estimates and sedimentation modeling. Proceedings of International Tsunami Symposium, 389-395.

Tomita, T., Imamura, F., Arikawa, T., Yasuda, T. and Kawata, Y. (2006) Damage caused by the 2004 Indian Ocean tsunami on the southwestern coast of Sri Lanka. Coastal Engineering Journal, 48, 99-116. Whelan, F. and Kelletat, D. (2005) Boulder deposits on the southern Spanish Atlantic coast : Possible evidence for the 1755 AD Lisbon tsunami? Science of Tsunami Hazards, 23, 25-38.
Yanagisawa, H., Koshimura, S., Goto, K., Imamura, F., Miyagi, T. and Hayashi, K. (2006) Tsunami inundation flow in the mangrove forest and criteria of tree damages-Field survey of the 2004 Indian Ocean Tsunami in Khao Lak, Thailand-. Annual Journal of Coastal Engineering, JSCE, 53, 231-235. (J)

Yasuda, T. and Harada, K. (2005) Sumatra earthquake tsunami disaster in December 26, 2004. Journal of Japan Society for Natural Disaster Science, 23, 603615. (J)

$(\mathrm{J})$ in Japanese, $(\mathrm{J}+\mathrm{E})$ in Japanese with English abstract.

\title{
津波による土砂・ブロック移動モデルの現状と課題
}

\author{
後 藤 和 久 $^{*}$ a $・$ 今 村 文 彦*
}

\begin{abstract}
〔要旨〕
津波に伴う土砂移動現象は, 海岸の地形変化や海洋・ 沿岸生態系の破壊などの重大な問題を引き起こす。本論 では，海岸工学の分野で開発・改良されてきた津波によ る土砂, ブロック移動の数值モデルの現状と課題の整理 を行い, 堆積学的研究との連携について考察した。これ らの数值モデルは, まだ課題は多いものの水槽実験結果 を比較的良好に再現できており，実スケールの現象に適

塊移動などに対応できるようモデルを拡張すれば，津波 堆積物や津波石を用いて, 過去に発生した津波の流体力 や流速などの水理量をより定量的に評価できるようにな ると考えられる. また, 土砂移動モデルを利用すること で, 海底での侵食・堆積量を評価することが可能であ り，津波堆積物を発見することを目的とした海底掘削地 点の選定にも役立つと考えられる。
\end{abstract} 用できる段階に達しつつある. 今後, 混合粒径や複数岩

キーワード : 津波堆積物, 津波石, 土砂移動モデル, 水槽実験

2006 年 8 月 10 日受付. 2007 年 1 月 13 日受理.

* 東北大学大学院工学研究科附属災害制御研究センター =980-8579 仙台市青葉区荒巻字青葉 6-6-11-1106.

*a Corresponding author : kgoto@tsunami2.civil.tohoku.ac.jp 